Article

\title{
The Synthesis of Secondary Iron Minerals Induced by Quartz Sand during the Bioleaching Process Improves the Dewaterability of Municipal Sewage Sludge
}

\author{
Yingying Ma, Heru Wang, Yongwei Song * ${ }^{\mathbb{C}}$, Yiqian $\mathrm{Wu}$ and Zehao Guo \\ Department of Environmental Science and Engineering, Zhongnan University of Economics and Law, \\ Wuhan 430073, China; 3266160myy@sina.com (Y.M.); z0004382@zuel.edu.cn (H.W.); vivixqk@sina.com (Y.W.); \\ gzh1162485884@163.com (Z.G.) \\ * Correspondence: songyongwei@zuel.edu.cn; Tel.: +86-027-8838-5169
}

Received: 18 August 2018; Accepted: 14 September 2018; Published: 20 September 2018

check for updates

\begin{abstract}
This study elucidated the mechanisms during the bioleaching process when optimizing the dewaterability of municipal sludge using quartz sand. The experiment was conducted with a shaking table and a series of controlled trials designed to investigate the influence of quartz sand on sludge dewaterability. Scanning electron microscopy and X-ray diffraction were applied to explore the quartz sand's action mechanism. Results indicated that quartz sand could improve the sludge bioleaching efficiency. The optimal reaction time was between $24-48 \mathrm{~h}$ and $48-72 \mathrm{~h}$ with and without $10 \mathrm{~g} \cdot \mathrm{L}^{-1}$ of quartz sand, and a minimum sludge specific resistance to filtration was $1.2 \times 10^{12}$ and $2.4 \times 10^{12} \mathrm{~m} \cdot \mathrm{kg}^{-1}$, respectively. Quartz sand could provide nucleating sites for secondary iron minerals and overcome the unfavorable influence of a low $\mathrm{Fe}^{3+}$ supply rate in the initial bioleaching stage $(0-24 \mathrm{~h})$. Because it was conducive to accelerating the initial mineral precipitation, quartz sand could improve bioleaching efficiency. The X-ray diffraction spectrum showed that quartz sand induced changes in the synthesis pathway of secondary iron minerals when the concentration of $\mathrm{Fe}^{2+} \geq 4 \mathrm{~g} \cdot \mathrm{L}^{-1}$. This then promoted the transformation of schwertmannite into jarosite during the mineralization process, which immobilizes nutrients such as $\mathrm{K}^{+}$and $\mathrm{NH}_{4}{ }^{+}$in the form of jarosite. Accordingly, bioleached sludge dewaterability and its utilization value can be improved. These results provide theoretical reference for improving bioleaching techniques in the treatment of municipal sludge.
\end{abstract}

Keywords: Acidithiobacillus ferrooxidans; quartz sand; municipal sewage sludge; secondary iron minerals; dewaterability

\section{Introduction}

Bioleaching is a harmless treatment technology that uses an Acidithiobacillus species (including A. ferrooxidans and $A$. thiooxidans) to treat sewage sludge [1,2]. Numerous studies have demonstrated that bioleaching can effectively remove heavy metals in sewage sludge while simultaneously improving the sludge dewaterability. Dewaterability indicates the degree of difficulty to achieve the solid-liquid separation of sewage sludge through filter media; it is commonly characterized by specific resistance to filtration (SRF) and capillary suction time (CST) [3,4]. For instance, after being treated with a bioleaching method, the SRF decreased by nearly $80 \%$, and after mechanical dewatering the sludge moisture content was less than $60 \%[5,6]$, which significantly reduces the sludge volume and improves subsequent sludge treatment. Liu et al. confirmed that 2.4 is the optimal $\mathrm{pH}$ value to promote the dewaterability of municipal sewage sludge in the bioleaching process. At this $\mathrm{pH}, \mathrm{H}^{+}$ions neutralize 
the sludge surface's negative charge to near-neutral to enhance the sewage sludge's coagulation and dehydration [7]. In addition to optimizing $\mathrm{pH}$, the energy sources, $\mathrm{FeSO}_{4}$ and $\mathrm{S}^{0}$, need to be added in order for the Acidithiobacillus species to improve the sludge system's bio-acidification efficiency. However, the strong hydrophobicity of $S^{0}$ inhibits its full utilization by $A$. thiooxidans during shorter periods, resulting in large quantities of residual $\mathrm{S}^{0}$ in sewage sludge at the end of bioleaching, thus impacting the utilization of dewatered sludge [8,9]. Ultimately, there are limits to adopting bioleaching technology mediated by A. ferrooxidans and A. thiooxidans to promote the dewaterability of municipal sludge.

During the sludge bioleaching process, A. ferrooxidans can improve sludge dewaterability by oxidizing $\mathrm{Fe}^{2+}$ to biological polymeric ferric sulfate, which has a flocculation effect on sludge particles [9]. Meanwhile, hydrolyzing $\mathrm{Fe}^{3+}$ from the bio-oxidation of $\mathrm{Fe}^{2+}$ will produce secondary iron minerals and release large amounts of $\mathrm{H}^{+}$lowering sludge $\mathrm{pH}[10,11]$. The reactions can be summarized as follows:

$$
\begin{gathered}
8 \mathrm{Fe}^{3+}+14 \mathrm{H}_{2} \mathrm{O}+\mathrm{SO}_{4}{ }^{2-} \rightarrow \mathrm{Fe}_{8} \mathrm{O}_{8}(\mathrm{OH})_{6} \mathrm{SO}_{4} \text { (schwertmannite) }+22 \mathrm{H}^{+} \\
\mathrm{M}^{+}+3 \mathrm{Fe}^{3+}+2 \mathrm{SO}_{4}{ }^{2-}+6 \mathrm{H}_{2} \mathrm{O} \rightarrow \mathrm{MFe}_{3}\left(\mathrm{SO}_{4}\right)_{2}(\mathrm{OH})_{6} \text { (jarosite) }+6 \mathrm{H}^{+}
\end{gathered}
$$

Among the reactions, $\mathrm{M}^{+}$refers to monovalent cations in sewage sludge such as $\mathrm{K}^{+}, \mathrm{Na}^{+}$, and $\mathrm{NH}_{4}{ }^{+}$. As stated above, there are two advantages to promoting the hydrolysis and mineralization of $\mathrm{Fe}^{3+}$. First, this process helps to accelerate sludge acidification so it can reach the optimum $\mathrm{pH}$ more quickly. Second, the increase in secondary iron minerals contributes to a decrease in the compressibility of the sludge needed to further improve sludge dewaterability [12]. In addition, the sewage sludge contains abundant agricultural nutrients such as $\mathrm{N}$ and $\mathrm{K}$. Promoting the biosynthesis of jarosite (Reaction 2) can immobilize $\mathrm{K}^{+}$or $\mathrm{NH}_{4}{ }^{+}$ions contained in the liquid phase into the solid phase. This decreases the loss of nutrient elements and reduces the risk of water eutrophication. Therefore, using the biomineralization of $A$. ferrooxidans to improve traditional sludge bioleaching technology not only prevents adverse effects brought by $A$. thiooxidans oxidizing $S^{0}$, which adds extra $S^{0}$ to bioleached sludge, but also improves the utilization value of bioleached sludge by introducing nutrient elements (such as $\mathrm{N}$ and $\mathrm{K}$ ) into the solid phase. In recent years, there have been several reports on the formation and characteristic of biogenic secondary iron minerals in the bioleaching system. These characteristics indicate that the secondary iron minerals absorb and coprecipitate heavy metals or metalloids in solutions, thus decreasing the leaching ratio of toxic elements in solid phases (e.g., tannery sludge and pig manure) $[13,14]$. When removing heavy metals in sludge through bioleaching, the secondary iron minerals that are formed can lead to negative effects. According to the Control Standards of Pollutants in Sludge for Agricultural Use (China, GB 4284-2018) [15], the heavy metal content in municipal sludge is of a low over-proof rate. For instance, by collating and counting the heavy metal content of Chinese municipal sludge reported in relevant literature (2006-2013), Guo et al. [16] concluded that the over-proof rate of the heavy metals $\mathrm{Cu}, \mathrm{Pb}, \mathrm{Zn}, \mathrm{Cd}, \mathrm{Hg}, \mathrm{As}, \mathrm{Cr}$, and $\mathrm{Ni}$ were $2.3 \%, 0 \%, 5.9 \%, 5.5 \%$, $2.9 \%, 0 \%, 0 \%$, and $3.5 \%$, respectively. Therefore, the critical objective in treating municipal sludge is to reduce the sludge volume. As mentioned previously, reducing the volume is possible using secondary iron minerals formation since it improves sludge dewaterability. However, regarding the sludge bioleaching system, there are no reports on how secondary iron mineral formation mediated by A. ferrooxidans specifically affects sludge dewaterability.

In general, the formation of biogenic secondary iron minerals can be roughly divided into three steps: $\mathrm{Fe}^{2+}$ is oxidized to $\mathrm{Fe}^{3+} ; \mathrm{Fe}^{3+}$ is hydrolyzed and forms mineral crystal nucleus; and the nucleus gradually agglomerates and expands [17]. These show that the formation of secondary iron minerals is a new phase formation process, closely relevant to the supply rate of $\mathrm{Fe}^{3+}$ in solution $[18,19]$. Dutrizac found that the addition of crystal seeds (sodium, ammonium, and potassium jarosites) can accelerate the hydrolysis and mineralization of $\mathrm{Fe}^{3+}$ and raise the mineral output [20]. Wang et al. also reported that employing quartz sand or diatomite as crystal seed has little influence on the $\mathrm{Fe}^{2+}$ 
bio-oxidation process and can help precipitate and remove $\mathrm{Fe}^{3+}$ in simulative acid mine drainage [21]. Based on this, we assume that the inductive effects of crystal seeds can promote the quick synthesis of secondary iron minerals and accelerate the sludge acidification rate, thus increasing the sludge bioleaching efficiency. The purpose of this study can be summarized as follows: (1) explore the specific effects of secondary iron minerals on municipal sludge dewaterability and (2) study the role of quartz sand in a bioleaching system mediated by A. ferrooxidans and mechanism by which quartz sand induces secondary iron mineral synthesis. We aim to find an optimal method to improve municipal sludge dewaterability and achieve sludge volume reduction. The study may also provide a theoretical reference for improvement in the municipal sludge bioleaching technique.

\section{Materials and Methods}

\subsection{Municipal Sewage Sludge Sample and Quartz Sand}

Municipal sewage sludge used in this study was collected from the sludge thickener of a wastewater treatment plant in Wuhan City, Hubei Province, China. The physicochemical properties of the sludge are as follows: a solid content of $2.1 \%$, a pH of 7.22 , an organic matter content of $49.4 \%$, a total $\mathrm{N}$ of $4.4 \%$, a total $\mathrm{P}$ of $3.5 \%$, a total $\mathrm{K}$ of $1.5 \%$, and a sludge SRF of $12.4 \times 10^{12} \mathrm{~m} \cdot \mathrm{kg}^{-1}$. The heavy metal content of municipal sludge was measured to be $\mathrm{Cu} 137.4, \mathrm{~Pb} 83.9, \mathrm{Zn} 219.6, \mathrm{Cd} \mathrm{0.7,} \mathrm{Hg} \mathrm{0}$, As 1.4, Cr 102.3, and Ni $26.2 \mathrm{mg} / \mathrm{kg}$, respectively. No heavy metal content exceeds the criterion [15]. Municipal sewage sludge was stored in polypropylene bottles at $4{ }^{\circ} \mathrm{C}$ before use. The particle size of quartz sand used in this study was 30-40 mesh. It was firstly soaked in $1 \mathrm{~mol} \cdot \mathrm{L}^{-1} \mathrm{H}_{2} \mathrm{SO}_{4}$ for $24 \mathrm{~h}$ and then dried for further use.

\subsection{Preparation of A. ferrooxidans LX5 Inoculum}

The acidophilic chemoautotrophic bacterium Acidothiobacillus ferrooxidans LX5 (CGMCC No. 0727) was obtained from the China General Microbiological Culture Collection Center (Beijing, China) and grown in modified $9 \mathrm{~K}$ medium. The $\mathrm{pH}$ value of the cultivation medium was 2.50 . The inoculum with an initial cell density of $10^{7}$ cells $\cdot \mathrm{mL}^{-1}$ was cultured in a gyratory shaker at $28^{\circ} \mathrm{C}$ and $180 \mathrm{rpm}$ for 3-4 days until the cell density reached $10^{8}$ cells $\cdot \mathrm{mL}^{-1}[3,22]$.

\subsection{The Influence of Quartz Sand on the Dewaterability of Sludge in the Bioleaching System Mediated} by A. ferrooxidans LX5

Using $1000 \mathrm{~mL}$ Erlenmeyer flasks, the sludge treatment is listed as follows: (1) $540 \mathrm{~mL}$ sludge $+60 \mathrm{~mL}$ deionized water; (2) $540 \mathrm{~mL}$ sludge $+60 \mathrm{~mL}$ deionized water $+10 \mathrm{~g} \cdot \mathrm{L}^{-1}$ quartz sand; (3) $540 \mathrm{~mL}$ sludge + $60 \mathrm{~mL}$ A. ferrooxidans $\mathrm{LX} 5+44.2 \mathrm{~g} \cdot \mathrm{L}^{-1} \mathrm{FeSO}_{4} \cdot 7 \mathrm{H}_{2} \mathrm{O}$; (4) $540 \mathrm{~mL}$ sludge $+60 \mathrm{~mL}$ A. ferrooxidans $\mathrm{LX} 5+44.2$ $\mathrm{g} \cdot \mathrm{L}^{-1} \mathrm{FeSO}_{4} \cdot 7 \mathrm{H}_{2} \mathrm{O}+10 \mathrm{~g} \cdot \mathrm{L}^{-1}$ quartz sand. Each treatment was tested three times. The initial cell density in every flask was $5 \times 10^{7}$ cells. $\mathrm{mL}^{-1}$. The flasks were incubated in a gyratory shaker at $28^{\circ} \mathrm{C}$ and $180 \mathrm{rpm}$ for $120 \mathrm{~h}$. Periodic samples were taken to monitor the sludge $\mathrm{pH}$ and dewaterability (characterized by SRF) during the process. With each sample, the flasks were shaken to mix the supernatant and were taken after $5 \mathrm{~s}$ for full sedimentation of quartz sand. The concentrations of $\mathrm{Fe}^{2+}$ were measured and its oxidation ratio was calculated via the following equation: $\mathrm{Fe}^{2+}$ oxidation efficiency $(\%)=\left(\mathrm{C}_{0}-\mathrm{C}_{\mathrm{t}}\right) / \mathrm{C}_{0} \times 100 \%$, where $\mathrm{C}_{0}$ is the initial $\mathrm{Fe}^{2+}$ concentration $\left(\mathrm{g} \cdot \mathrm{L}^{-1}\right)$, and $\mathrm{C}_{\mathrm{t}}$ is the $\mathrm{Fe}^{2+}$ concentration $\left(\mathrm{g} \cdot \mathrm{L}^{-1}\right)$ at different times.

The residual sludge in Erlenmeyer flasks was collected at the termination of culture and grinded into powder with agate mortar after dried at $55{ }^{\circ} \mathrm{C}$. Scanning electron microscope (SEM) was applied to observe the appearance features of dried sludge samples.

\subsection{The Influence of Quartz Sand on the Formation of Secondary Iron Minerals in the Bioleaching System Mediated by A. ferrooxidans LX5}

$\mathrm{FeSO}_{4} \cdot 7 \mathrm{H}_{2} \mathrm{O}$ was supplemented with an $\mathrm{Fe}^{2+}$ concentration gradient of $8,6,4$, and $2 \mathrm{~g} \cdot \mathrm{L}^{-1}$ into a series of Erlenmeyer flasks each containing $270 \mathrm{~mL}$ of sludge leachate. Using different concentrations, each group was further divided into two groups, with one group receiving $10 \mathrm{~g} \cdot \mathrm{L}^{-1}$ of quartz sand. 
Thirty-milliliter A. ferrooxidans LX5 suspensions were inoculated at $10 \%(v / v)$, which increased the total volume of liquid to $300 \mathrm{~mL}$. Each treatment was tested three times. The flasks were incubated in a gyratory shaker at $28{ }^{\circ} \mathrm{C}$ and $180 \mathrm{rpm}$ for $120 \mathrm{~h}$. Samples were taken periodically to measure the $\mathrm{pH}$ and concentrations of $\mathrm{Fe}^{2+}, \mathrm{Fe}^{3+}$, and total $\mathrm{Fe}(\mathrm{TFe})$. The TFe fractional precipitation efficiency as well as the cumulative precipitation efficiency in the termination of culture were calculated via the following equations: TFe fractional precipitation efficiency $(\%)=\left(C_{t 1}^{\prime}-C_{t 2}^{\prime}\right) / C_{0}^{\prime} \times 100 \%$, and TFe cumulative precipitation efficiency $(\%)=\left(C_{0}^{\prime}-C_{120}^{\prime}\right) / C_{0}^{\prime} \times 100 \%$, where $C_{0}^{\prime}$ is the initial TFe concentration $\left(\mathrm{g} \cdot \mathrm{L}^{-1}\right), \mathrm{C}_{\mathrm{t} 1}^{\prime}$ or $\mathrm{C}_{\mathrm{t} 2}^{\prime}$ is the TFe concentration $\left(\mathrm{g} \cdot \mathrm{L}^{-1}\right)$ at $\mathrm{t}_{1}$ or $\mathrm{t}_{2} \mathrm{~h}$, and $\mathrm{C}^{\prime}{ }_{120}$ is the TFe concentration $\left(\mathrm{g} \cdot \mathrm{L}^{-1}\right)$ at $120 \mathrm{~h}$.

The secondary iron minerals synthesized at terminal were collected by filtering using Whatman No. 4 filter paper and were then dried at $55^{\circ} \mathrm{C}$ to constant weight. The mineral phases of the dried solid precipitates was determined using power X-ray diffraction (XRD).

\subsection{Analytical Methods}

Sludge $\mathrm{pH}$ was measured using a $\mathrm{pHS}-3 \mathrm{C}$ precise $\mathrm{pH}$ meter with a resolution of $0.01 \mathrm{pH}$ unit. The SRF was determined by filtrating $50 \mathrm{~mL}$ sludge sample in a Buchner funnel with a filter paper disc (Whatman No. 4) and $0.08 \mathrm{MPa}$ suction pressure. The time required for the collection of every $5 \mathrm{~mL}$ of the filtrate was recorded and the SRF was calculated according to the method of Murugesan et al. [9]. The solid content and organic matter content of sludge was determined by drying at $105^{\circ} \mathrm{C}$ and combustion at $600{ }^{\circ} \mathrm{C}$, respectively [23]. The concentrations of $\mathrm{Fe}^{2+}, \mathrm{Fe}^{3+}$, and TFe were determined using the 1,10-phenanthroline method by a spectrophotometer (721, XTZ Optical Instrument Factory, Shanghai, China) with a detection wavelength at $530 \mathrm{~nm}$ [23]. The morphology of minerals was observed by scanning electron microscope (SEM, SU8010, Hitachi Limited, Tokyo, Japan), and the mineral phase was determined by X-ray diffraction (XRD, Bruker D8A25, Bruker Corporation, Karlsruhe, Germany) using $\mathrm{Cu} \mathrm{K} \alpha$ radiation $(40 \mathrm{kV}, 40 \mathrm{~mA}$ ) [24]. According to the Control Standards of Pollutants in Sludge for Agricultural Use (GB 4284-2018) [15], the Cd and Pb in municipal sludge was measured by graphite furnace atomic absorption spectrometry (YCA-1000G, Yuwei Technology, Beijing, China). $\mathrm{Hg}$ and As was determined by atomic fluorescence spectrometry (AFS-9730, Haiguang Instrument, Beijing, China). $\mathrm{Cr}, \mathrm{Ni}, \mathrm{Zn}$, and $\mathrm{Cu}$ was measured by flame atomic absorption spectrophotometry (Agilent 7700e, Agilent Technologies, Santa Clara, CA, USA).

\subsection{Statistical Analysis}

The statistical analysis was graphically carried out with Origin software version 8.0. The data shown in the figures was presented as mean values with standard deviations to indicate the reproducibility and reliability of the results.

\section{Results and Discussion}

\subsection{The Influence of Quartz Sand on the $p H$, Oxidation Efficiency of Fe ${ }^{2+}$, SRF in Sludge Bioleaching System}

The influence of quartz sand on the $\mathrm{pH}, \mathrm{Fe}^{2+}$ oxidation efficiency, and SRF of sludge in a bioleaching system is illustrated in Figure 1. In culture, the $\mathrm{pH}$ in both the original sludge system and the sludge system infused with quartz sand declined slowly. The variation curves of these two cultures essentially agreed according to the sludge nitration with the minimum pH ranging from 5.62 to 5.79. This result demonstrated that the quartz sand alone did not have a significant effect on sludge $\mathrm{pH}$. Affected by the low $\mathrm{pH}$ of the $A$. ferrooxidans LX5 suspensions, the original sludge $\mathrm{pH}$ declined from 7.57 to $5.774 \mathrm{~h}$ post-inoculation. With the extension of the bioleaching time, $A$. ferrooxidans LX5 gradually adapted to the sludge system and began to use $\mathrm{Fe}^{2+}$ energy sources to supply cell metabolism. The $\mathrm{Fe}^{3+}$, oxidized from $\mathrm{Fe}^{2+}$, released $\mathrm{H}^{+}$through hydrolysis, accelerating sludge acidification. The $\mathrm{pH}$ of the sludge system decreased rapidly in the initial bioleaching stage (0-72 h) and then became stable. This result occurred because the slow growth period for the A. ferrooxidans LX5 was relatively short 
and the cells quickly entered the logarithmic period and propagated rapidly. When the energy sources were exhausted, the $A$. ferrooxidans LX5 reached an invariable period, with little effect on the changes to sludge $\mathrm{pH}$. As observed in Figure 1a, when sludge is inoculated and supplemented with $\mathrm{Fe}^{2+}$, introducing quartz sand significantly improves the acidification rate and degree. Based on the $\mathrm{Fe}^{2+}$ oxidation levels (Figure $1 \mathrm{~b}$ ), there were no significant effects on the $\mathrm{Fe}^{2+}$ bio-oxidizing efficiency with and without quartz sand. In the sludge system treated with only A. ferrooxidans LX5 and supplemented with both $A$. ferrooxidans LX5 and quartz sand, the $\mathrm{Fe}^{2+}$ oxidation efficiencies were $35 \%$ and $100 \%$ at $24 \mathrm{~h}$ and $48 \mathrm{~h}$, respectively. The changes in the sludge $\mathrm{pH}$ and the $\mathrm{Fe}^{2+}$ oxidizing efficiency indicated that the quartz sand promoted the acidification effects of bioleached sludge because it accelerated the hydrolysis process of bio-oxidation products $\left(\mathrm{Fe}^{3+}\right)$. Liu et al. reported that 2.4 is the optimum $\mathrm{pH}$ to promote municipal sewage sludge dewaterability during the bioleaching process [7]. As shown in Figure 1a,b, the inoculation treatment without quartz sand reached the optimum critical $\mathrm{pH}$ point for dewatering after bioleaching between 48 and $72 \mathrm{~h}$, while $10 \mathrm{~g} \cdot \mathrm{L}^{-1}$ quartz sand could shorten the bioleaching time to $24-48 \mathrm{~h}$ by accelerating the hydrolysis of $\mathrm{Fe}^{3+}$ to release $\mathrm{H}^{+}$.

From the sludge SRF perspective, the sludge dewaterability in each treatment improved to a certain degree (Figure 1c). For instance, the SRF of the original sludge gradually decreased from $12.4 \times 10^{12} \mathrm{~m} \cdot \mathrm{kg}^{-1}$ initially to a minimum of $7.9 \times 10^{12} \mathrm{~m} \cdot \mathrm{kg}^{-1}$ at $96 \mathrm{~h}$. After adding $10 \mathrm{~g} \cdot \mathrm{L}^{-1}$ of quartz sand, the $\mathrm{pH}$ of the original sludge did not change significantly, but the SRF index showed that the quartz sand had an adverse effect on sludge dewaterability, manifesting as a rapid rise in SRF after it declined to $10.8 \times 10^{12} \mathrm{~m} \cdot \mathrm{kg}^{-1}$ at $24 \mathrm{~h}$. Analysis suggested that the durable characteristics of the quartz sand changed the sludge's physical properties so that it congealed during flocculation, then broke and dissolved due to the dynamic hydraulic shear and grinding effects of the quartz sand over a long period of time. The sludge particle size declined, which resulted in fine granules blocking the filter media, thus increasing filtration resistance and decreasing the filtration ability (verified by Figure 2). By comparison, the dewaterability of sludge inoculated with A. ferrooxidans LX5 improved significantly and the sludge SRF decreased to $3.6 \times 10^{12} \mathrm{~m} \cdot \mathrm{kg}^{-1}$ at $24 \mathrm{~h}$. Moreover, although the quartz sand supplement proved to adversely affect sludge dewaterability, the SRF variation trend reflected that the quartz sand supplement continued to have a positive effect on improving sludge dewaterability in the initial bioleaching stage, with the sludge SRF decreasing to a minimum of $1.2 \times 10^{12} \mathrm{~m} \cdot \mathrm{kg}^{-1}$ within $24 \mathrm{~h}$. Compared to the treatment without quartz sand, the bioleaching method using $A$. ferrooxidans LX5 and quartz sand both further improved the sludge dewaterability and shortened the bioleaching time accordingly, which is essential to adopting the bioleaching method mediated by $A$. ferrooxidans LX5 to treat municipal sewage sludge.

To remove heavy metals in the solid phase, Liao et al. [13] and Zhou et al. [14] observed the occurrence of secondary iron minerals in separate bioleaching processes for tannery sludge and pig manure. The X-ray diffraction results revealed that the collected minerals were pure schwertmannite and a mixture of schwertmannite and jarosite, respectively $[13,14]$. The differences in the bioleaching target characteristics also affected the biosynthesis method for secondary iron minerals. In addition, previous researchers have not observed the appearance features of the derivative minerals in the municipal sewage sludge bioleaching system. As shown in Figure 2, the samples from non-treated sludge had irregular colloidal structures and formed clusters during flocculation (Figure 2a). After being treated with quartz sand, the flocculation structure of the original sludge dispersed and the sludge particles were comparatively well distributed; irregular particles in bulk could be clearly observed (Figure 2b). Compared with the original sludge, there were particles shaped like "myrica rubra" inlaid in the flocculation structure of the bioleached sludge; these particles were approximately $3 \mu \mathrm{m}$ in diameter and covered with acerate burr (Figure 2c). Loan et al. found that schwertmannite, with the structure of a spherical "sea urchin," would form in an acidic sulfate environment rich in $\mathrm{Fe}$, the surface of which was also covered with acerate burr at a length of approximately 60-90 nm [25-28]. As inferred, the study particles that were shaped like "myrica rubra" were likely schwertmannite. In addition, smooth blocks were observed attached to sludge particles 
in the treated samples. According to the findings of Liao et al. [13] and Zhou et al. [14], we assume that the minerals might be jarosite. However, in the bioleaching system supplemented with quartz sand, there was no occurrence of schwertmannite's unique spherical structure and only some jarosite could be observed in the sludge particles. Therefore, we deduced that the quartz sand might change the way in which $\mathrm{Fe}^{3+}$ is hydrolyzed and mineralized, indicating a tendency to synthesize jarosite in its synthesis process.

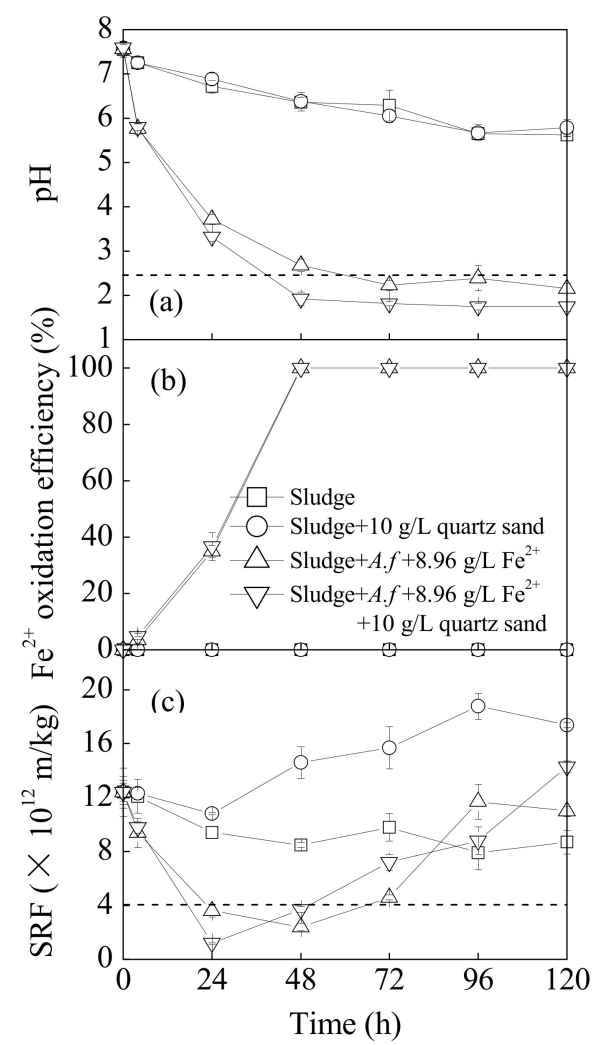

Figure 1. Changes in sludge (a) $\mathrm{pH},(\mathbf{b}) \mathrm{Fe}^{2+}$ oxidation efficiency, and (c) specific resistance to filtration (SRF) upon different treatments at $28^{\circ} \mathrm{C}$ and $180 \mathrm{rpm}$ for $120 \mathrm{~h}$ : (1) sludge: $540 \mathrm{~mL}$ sludge $+60 \mathrm{~mL}$ deionized water; (2) sludge $+10 \mathrm{~g} \cdot \mathrm{L}^{-1}$ quartz sand: $540 \mathrm{~mL}$ sludge $+60 \mathrm{~mL}$ deionized water $+10 \mathrm{~g} \cdot \mathrm{L}^{-1}$ quartz sand; (3) sludge $+A \cdot f+8.96 \mathrm{~g} \cdot \mathrm{L}^{-1} \mathrm{Fe}^{2+}: 540 \mathrm{~mL}$ sludge $+60 \mathrm{~mL}$ A. ferrooxidans $\mathrm{LX} 5+44.2 \mathrm{~g} \cdot \mathrm{L}^{-1} \mathrm{FeSO}_{4} \cdot 7 \mathrm{H}_{2} \mathrm{O}$; (4) sludge $+A \cdot f+8.96 \mathrm{~g} \cdot \mathrm{L}^{-1} \mathrm{Fe}^{2+}+10 \mathrm{~g} \cdot \mathrm{L}^{-1}$ quartz sand: $540 \mathrm{~mL}$ sludge $+60 \mathrm{~mL}$ A. ferrooxidans $\mathrm{LX} 5+44.2 \mathrm{~g} \cdot \mathrm{L}^{-1} \mathrm{FeSO}_{4} \cdot 7 \mathrm{H}_{2} \mathrm{O}+10 \mathrm{~g} \cdot \mathrm{L}^{-1}$ quartz sand (initial $\mathrm{pH}=7.22, \mathrm{SRF}=12.4 \times 10^{12} \mathrm{~m} \cdot \mathrm{kg}^{-1}$, A. ferrooxidans $\mathrm{LX} 5$ density $=5 \times 10^{7}$ cells $\left.\cdot \mathrm{mL}^{-1}\right)$.

3.2. The Influence of Quartz Sand on the Formation of Secondary Iron Minerals in the Bioleaching System Mediated by A. Ferrooxidans LX5

It is necessary to identify the sediment mineral phase to further demonstrate whether quartz sand can change the synthesis of biogenic secondary iron minerals in sludge systems. Based on the complex composition of municipal sludge, the secondary iron minerals would combine with sludge particles and influence identification during the mineral phase. Therefore, it is extremely important to substitute sludge for sludge leachate in order to investigate the formation and properties of biogenic secondary iron minerals. In addition, it has been noted in previous experiments that, when the concentration of the energy source, $\mathrm{FeSO}_{4} \cdot 7 \mathrm{H}_{2} \mathrm{O}$, was $44.2 \mathrm{~g} \cdot \mathrm{L}^{-1}$ in the sludge system (that is, the concentration of $\mathrm{Fe}^{2+}$ was $8.9 \mathrm{~g} \cdot \mathrm{L}^{-1}$ ), adding $10 \mathrm{~g} \cdot \mathrm{L}^{-1}$ of quartz sand could accelerate the sludge acidification and improve sludge dewaterability, with the sludge $\mathrm{pH}$ declining to a minimum of 1.74 . Decreasing the energy source dosage helped lower sludge treatment costs, which is essential in optimizing bioleaching 
technology. Nevertheless, there have been no reports on the effects of mineralizing quartz sand to induce low concentrations of $\mathrm{Fe}^{2+}$ in the sludge bioleaching system.
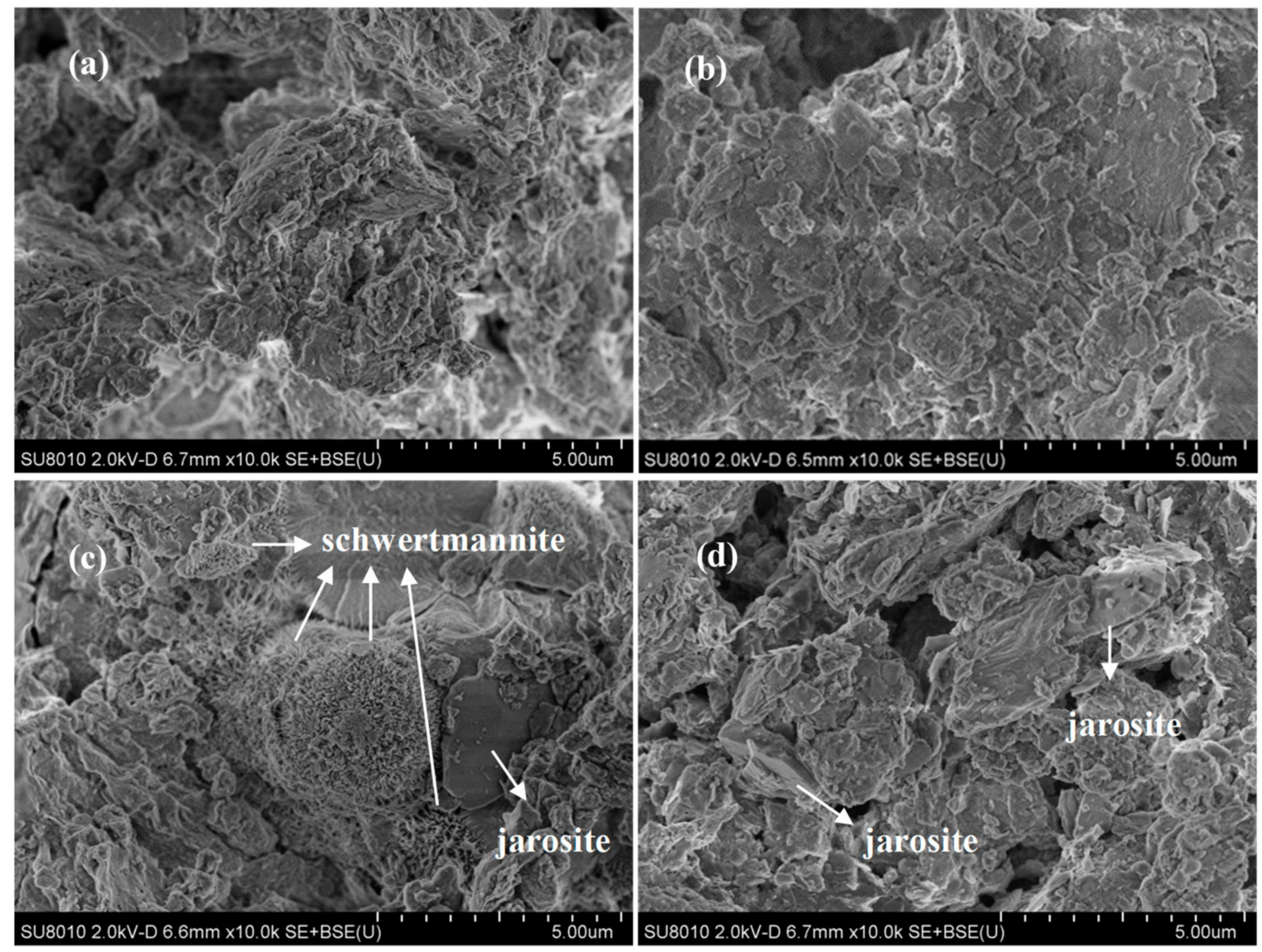

Figure 2. The scanning electron microscope (SEM) photos of municipal sewage sludge with different treatments at $28{ }^{\circ} \mathrm{C}$ and $180 \mathrm{rpm}$ for $120 \mathrm{~h}$ : (a) $540 \mathrm{~mL}$ sludge $+60 \mathrm{~mL}$ deionized water; (b) $540 \mathrm{~mL}$ sludge $+60 \mathrm{~mL}$ deionized water $+10 \mathrm{~g} \cdot \mathrm{L}^{-1}$ quartz sand; (c) $540 \mathrm{~mL}$ sludge $+60 \mathrm{~mL}$ A. ferrooxidans $\mathrm{LX} 5+44.2 \mathrm{~g} \cdot \mathrm{L}^{-1} \mathrm{FeSO}_{4} \cdot 7 \mathrm{H}_{2} \mathrm{O} ;$ (d) $540 \mathrm{~mL}$ sludge $+60 \mathrm{~mL}$ A. ferrooxidans $\mathrm{LX} 5+44.2 \mathrm{~g} \cdot \mathrm{L}^{-1} \mathrm{FeSO}_{4} \cdot 7 \mathrm{H}_{2} \mathrm{O}+10 \mathrm{~g} \cdot \mathrm{L}^{-1}$ quartz sand (initial $\mathrm{pH}=7.22, \mathrm{SRF}=12.4 \times 10^{12} \mathrm{~m} \cdot \mathrm{kg}^{-1}$, A. ferrooxidans $\mathrm{LX} 5$ density $=5 \times 10^{7}$ cells $\cdot \mathrm{mL}^{-1}$ ).

3.2.1. The Influence of Quartz Sand on the $\mathrm{pH}$, Concentrations of $\mathrm{Fe}^{2+}$ and $\mathrm{Fe}^{3+}$ in the Bioleaching System Mediated by A. Ferrooxidans LX5

Changes in the indexes in the sludge leachate system under different concentrations of energy sources are illustrated in Figure 3. Previous studies have demonstrated that, when the solution $\mathrm{pH}>$ 5 , the oxidation efficiency of $\mathrm{Fe}^{2+}$ is positively correlated with $\mathrm{pH}$ value. With one unit increments for $\mathrm{pH}$, the oxidation efficiency of $\mathrm{Fe}^{2+}$ would increase 100-fold [29]. However, when $\mathrm{pH}<3.5$, the oxidation efficiency of $\mathrm{Fe}^{2+}$ was independent of $\mathrm{pH}$ with a low oxidation efficiency constant of $10^{-3.5} \cdot \mathrm{d}^{-1}$ [30]. In an acidic environment, $A$. ferrooxidans can increase the oxidation efficiency of $\mathrm{Fe}^{2+}$ by $10^{5}-10^{6}$ times [31]. The oxidation of $\mathrm{Fe}^{2+}$ by $A$. ferrooxidans LX5 included two acid-participating steps: the acid-consuming bio-oxidation process for $\mathrm{Fe}^{2+}$ and the acid-generating hydrolysis and mineralization of $\mathrm{Fe}^{3+}$. Therefore, the oxidation degree of $\mathrm{Fe}^{2+}$ and the mineralization degree of $\mathrm{Fe}^{3+}$ could be approximated based on the changing trends in the reaction system $\mathrm{pH}$. As shown in Figure 3, in the treatment without quartz sand, the $\mathrm{pH}$ value of leachate was essentially trending upwards within $0-24 \mathrm{~h}$, which indicated that the primary reaction during this period was the bio-oxidation of $\mathrm{Fe}^{2+}$. Afterwards, the $\mathrm{pH}$ began to rapidly decrease and then tended to decrease slightly at $48 \mathrm{~h}$, suggesting that the reaction at 24-28 h was mainly the hydrolysis of $\mathrm{Fe}^{3+}$. When $\mathrm{Fe}^{2+}$ was entirely oxidized, it reduced the acid produced by the $\mathrm{Fe}^{3+}$ hydrolysis. After it was supplemented with 
$10 \mathrm{~g} \cdot \mathrm{L}^{-1}$ of quartz sand, the system $\mathrm{pH}$ began to decrease within $0-24 \mathrm{~h}$. This result is compared with the treatment without quartz sand, despite the fact that there was a consistent $\mathrm{Fe}^{2+}$ oxidation efficiency in both treatments at different stages. This result suggested that quartz sand could accelerate the hydrolysis and mineralization of $\mathrm{Fe}^{3+}$. After being bioleached for $48 \mathrm{~h}$, the $\mathrm{Fe}^{3+}$ hydrolysis and mineralization could still proceed quickly and continuously, the manifestations being that the system $\mathrm{pH}$ treated with $8,6,4$, and $2 \mathrm{~g} \cdot \mathrm{L}^{-1} \mathrm{Fe}^{2+}$ decreased to $1.77,1.83,2.04$, and 2.08 at $120 \mathrm{~h}$, respectively. Compared with the treatment without quartz sand under the same conditions, the $\mathrm{pH}$ decreased by $0.32,0.33,0.22$, and 0.09 , respectively. This further illustrates that quartz sand could promote the hydrolysis and mineralization of $\mathrm{Fe}^{3+}$, as confirmed by the changing trends in $\mathrm{Fe}^{3+}$ concentrations as shown in Figure 3.
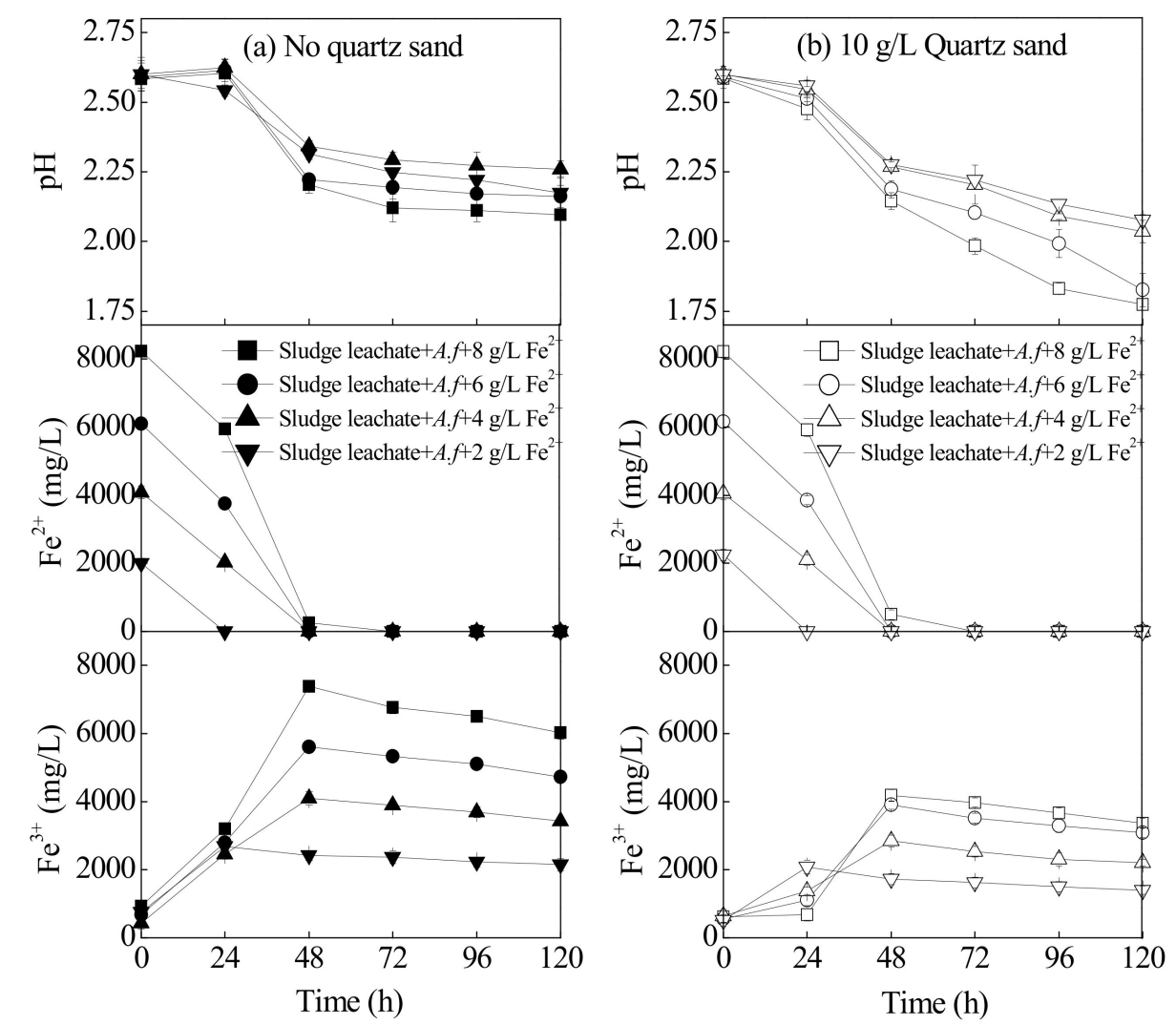

Figure 3. The index change ( $\mathrm{pH}, \mathrm{Fe}^{2+}$ and $\mathrm{Fe}^{3+}$ concentration) in the municipal sewage sludge with different treatments at $28^{\circ} \mathrm{C}$ and $180 \mathrm{rpm}$ for $120 \mathrm{~h}$ : (a) no quartz sand; (b) $10 \mathrm{~g} \cdot \mathrm{L}^{-1}$ quartz sand (initial $\mathrm{pH}=2.55, \mathrm{Fe}^{2+}$ concentration $=2-8 \mathrm{~g} \cdot \mathrm{L}^{-1}$, sludge leachate volume $=270 \mathrm{~mL}$, A. ferrooxidans LX5 volume $=30 \mathrm{~mL}$, A. ferrooxidans $\mathrm{LX} 5$ density $=5 \times 10^{7}$ cells $\cdot \mathrm{mL}^{-1}$ ).

3.2.2. The Influence of Quartz Sand on the Precipitation of TFe in the Bioleaching System Mediated by $A$. Ferrooxidans LX5

Figure 4 shows a comparison of the TFe fractional precipitation efficiency and accumulated precipitation efficiency with different treatments during different reaction periods. Essentially, in this process, the $\mathrm{Fe}^{3+}$ in the solutions was transferred from the liquid phase to the solid phase as it was hydrolyzed into secondary iron minerals during the bio-oxidation of $\mathrm{Fe}^{2+}$ [32]. Overall, introducing quartz sand or increasing the concentration of the energy source, $\mathrm{Fe}^{2+}$ in the bioleaching system improved the hydrolysis and sedimentation of $\mathrm{Fe}^{3+}$. For example, $10 \mathrm{~g} \cdot \mathrm{L}^{-1}$ of quartz sand could improve the TFe precipitation efficiency of system treated with $8,6,4$, or $2 \mathrm{~g} \cdot \mathrm{L}^{-1} \mathrm{Fe}^{2+}$ from $34.2 \%, 30.5 \%$, $24.0 \%$, and $21.9 \%$ to $85.3 \%, 69.9 \%, 68.3 \%$, and $61.9 \%$, respectively. In general, high concentrations of $\mathrm{Fe}^{3+}$ benefit the secondary iron mineral synthesis [33]. The results of this study indicated that 
a large number of secondary iron minerals could form in low $\mathrm{Fe}^{3+}$ concentrations when quartz sand is supplemented as crystal seed.
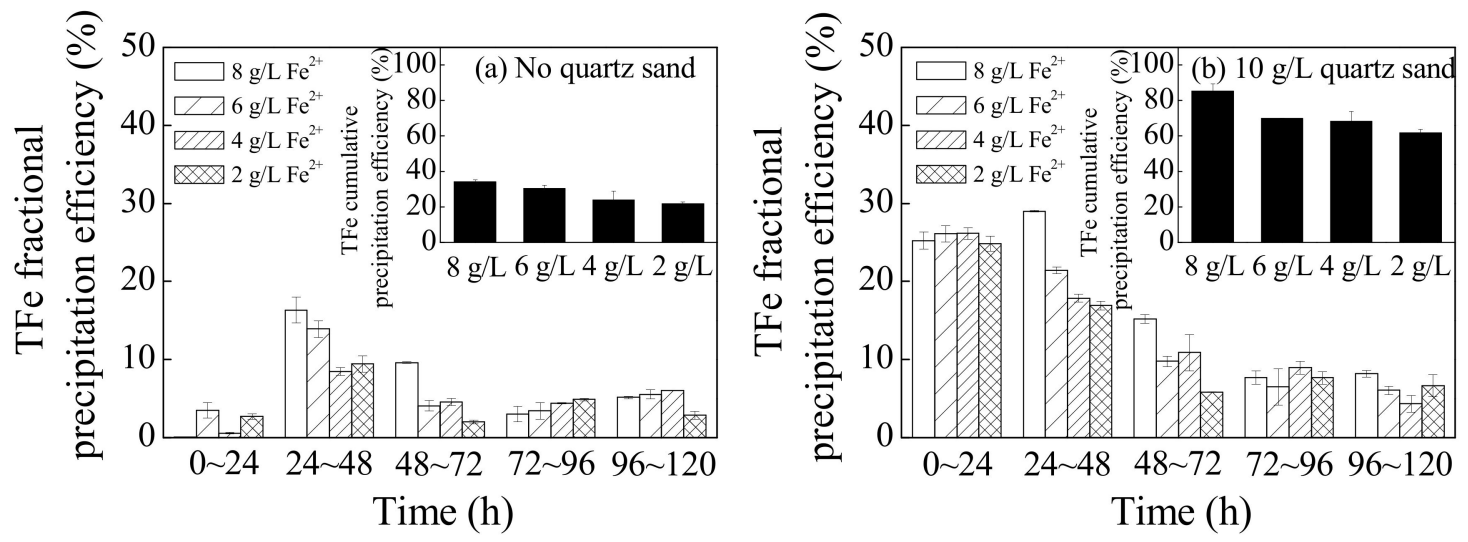

Figure 4. The changes in total Fe (TFe) precipitation efficiency in the municipal sewage sludge leachate with different treatments at $28^{\circ} \mathrm{C}$ and $180 \mathrm{rpm}$ for $120 \mathrm{~h}$ : (a) no quartz sand; (b) $10 \mathrm{~g} \cdot \mathrm{L}^{-1}$ quartz sand (initial $\mathrm{pH}=2.55, \mathrm{Fe}^{2+}$ concentration $=2-8 \mathrm{~g} \cdot \mathrm{L}^{-1}$, sludge leachate volume $=270 \mathrm{~mL}$, A. ferrooxidans $\mathrm{LX} 5$ volume $=30 \mathrm{~mL}, A$. ferrooxidans $\mathrm{LX} 5$ density $=5 \times 10^{7}$ cells $\cdot \mathrm{mL}^{-1}$ ).

In terms of the fractional TFe deposition efficiency, the TFe precipitation for all batches treated without quartz sand primarily occurred between 24 and $48 \mathrm{~h}$, accounting for $40-50 \%$ of the cumulative TFe deposition efficiencies, among which the worst precipitation effects occurred between 0 and 24 h. Introducing quartz sand mainly improved the TFe deposition efficiencies between 0 and $48 \mathrm{~h}$ and the TFe deposition efficiency during this period accounted for more than $60 \%$ of the cumulative efficiency. As shown in Figures 1 and 3, the supply rate of $\mathrm{Fe}^{3+}$ was low between 0 and $24 \mathrm{~h}$ resulting from the relatively slow $\mathrm{Fe}^{2+}$ oxidation efficiency, which then inhibited the formation of secondary iron minerals [15,34]. Employing quartz sand as crystal seed could overcome the adverse effects of low $\mathrm{Fe}^{3+}$ concentrations and significantly promote the hydrolysis and mineralization of $\mathrm{Fe}^{3+}$. Dutrizac demonstrated the following: the formation of secondary iron minerals is a new phase formation process; the initial TFe precipitation efficiency is slow due to the existence of an induction period; and crystal seed could provide nucleating sites for secondary iron minerals, accelerate the initial precipitation of minerals, and shorten the reaction stability time [20]. When $\mathrm{Fe}^{2+}$ was entirely oxidized and the induction period ended (48-120 h), the effect of quartz sand as crystal seed slightly decreased. However, as observed in Figure 1, the optimum reaction time to promote the dewaterability of bioleached sludge mediated by $A$. ferrooxidans LX5 was $24-48 \mathrm{~h}$, after which the hydrolysis and mineralization effects had little influence on sludge dewaterability.

3.2.3. The Influence of Quartz Sand on the Synthesis of Secondary Minerals in the Bioleaching System Mediated by A. Ferrooxidans LX5

Figure 5 shows the XRD spectrum of secondary iron minerals collected at the termination of culture in sludge leachate under different treatment. Referring to the spectrum of JCPDS crystalline jarosite (No: 22-0827) and amorphous schwertmannite (No: 47-1775) [26,35], improving concentrations of energy sources is known to benefit jarosite formation. For instance, when the concentration of $\mathrm{Fe}^{2+}$ rose from 2 to $8 \mathrm{~g} \cdot \mathrm{L}^{-1}$, the secondary iron minerals gradually transformed from schwertmannite to a mixture of schwertmannite and jarosite, and gradually intensive diffraction peaks of jarosite were observed. Regenspurg et al. attributed this phenomenon to the high $\mathrm{Fe}^{3+}$ supply rate in the system [34]. By comparison, when $\mathrm{Fe}^{2+} \geq 4 \mathrm{~g} \cdot \mathrm{L}^{-1}$, adding $10 \mathrm{~g} \cdot \mathrm{L}^{-1}$ quartz sand can induce and promote the transformation of the secondary iron minerals synthesis process, making it easier to obtain jarosite. We learned from Reactions (1) and (2) that the jarosite mass generated per $\mathrm{Fe}^{3+}$ unit should be 1.5 times more than schwertmannite, if the secondary iron minerals were synthesized through a single path. 
If so, this process makes it possible to produce more secondary iron minerals, thus improving the dewaterability of bioleached sludge. Moreover, when it is easier to form jarosite, the nutrients in the liquid phase can be immobilized, which increases the utilization value of the sludge. There was no sign of diffraction peaks of ammonium jarosite in this study, which might result from a low concentration of $\mathrm{NH}_{4}{ }^{+}$in the sludge leachate.
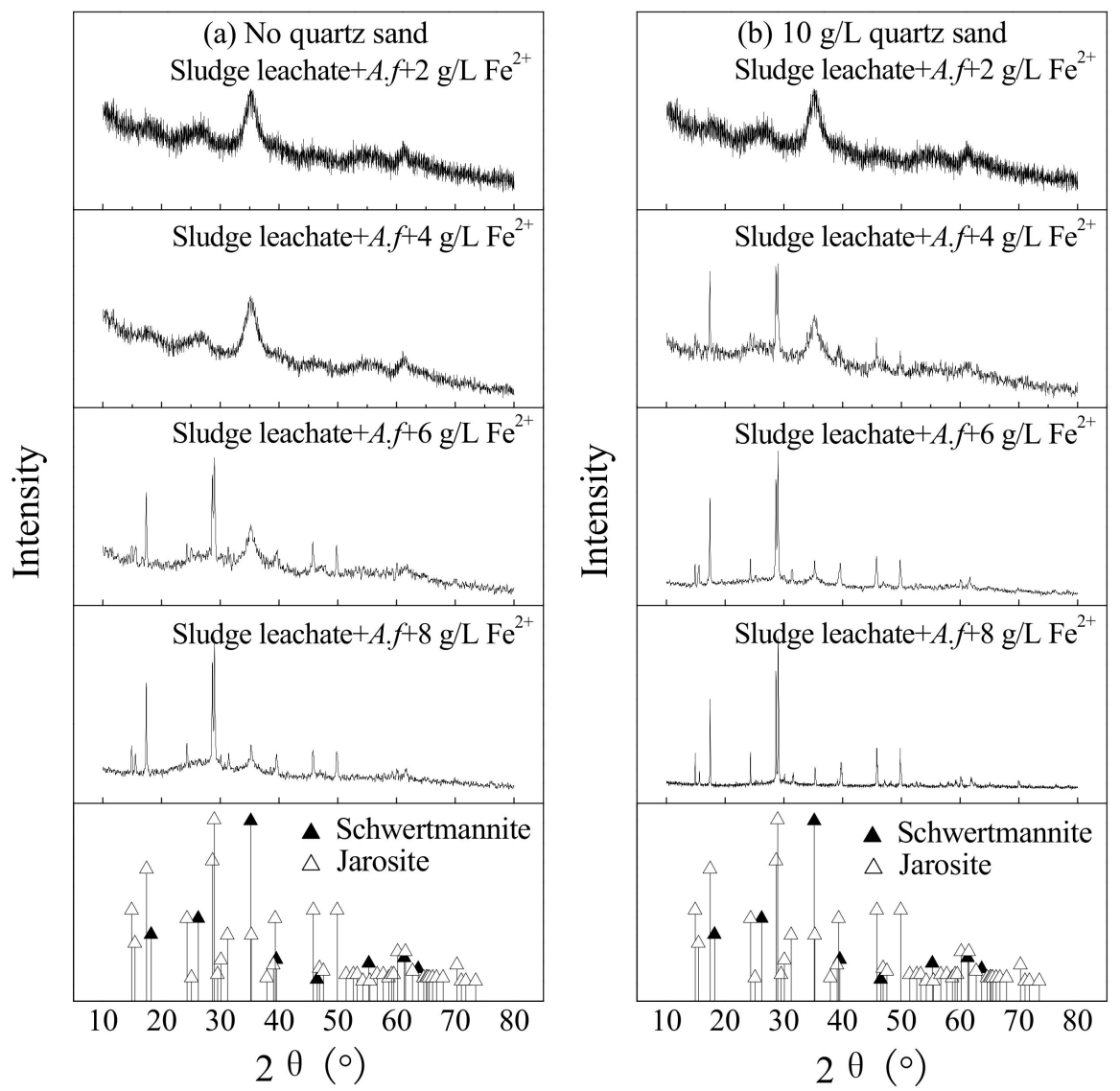

Figure 5. The XRD pattern of biogenic secondary iron minerals under different treatments at $28^{\circ} \mathrm{C}$ and $180 \mathrm{rpm}$ for $120 \mathrm{~h}$ : (a) no quartz sand; (b) $10 \mathrm{~g} \cdot \mathrm{L}^{-1}$ quartz sand (initial $\mathrm{pH}=2.55, \mathrm{Fe}^{2+}$ concentration $=2-8 \mathrm{~g} \cdot \mathrm{L}^{-1}$, sludge leachate volume $=270 \mathrm{~mL}$, A. ferrooxidans $\mathrm{LX} 5$ volume $=30 \mathrm{~mL}$, A. ferrooxidans LX5 density $=5 \times 10^{7}$ cells $\cdot \mathrm{mL}^{-1}$ ).

\section{Conclusions}

This study investigated the utilization and mechanism of quartz sand to improve sludge dewaterability during the bioleaching process. The results showed that quartz sand could improve sludge bioleaching efficiency and promote the sludge acidification degree. We found that the optimal reaction time was $24-48 \mathrm{~h}$ and $48-72 \mathrm{~h}$ with and without $10 \mathrm{~g} \cdot \mathrm{L}^{-1}$ quartz sand, respectively, and that the minimum sludge SRF was measured to be $1.2 \times 10^{12} \mathrm{~m} \cdot \mathrm{kg}^{-1}$ and $2.4 \times 10^{12} \mathrm{~m} \cdot \mathrm{kg}^{-1}$, respectively. Our analysis indicated that quartz sand could overcome the unfavorable influence of a low $\mathrm{Fe}^{3+}$ supply rate in the initial bioleaching stage $(0-24 \mathrm{~h})$, accelerate the initial mineral precipitation, shorten the reaction time, and improve bioleaching efficiency. When the concentration of $\mathrm{Fe}^{2+} \geq 4 \mathrm{~g} \cdot \mathrm{L}^{-1}$, adding $10 \mathrm{~g} \cdot \mathrm{L}^{-1}$ quartz sand could induce changes to the synthesis pathway of secondary iron minerals, which promotes the transformation of schwertmannite into jarosite during the mineralization process. In conclusion, comprehensively considering the elements of the sludge acidification rate, SRF, TFe precipitation efficiency, and the secondary iron minerals phase, when supplemented with $10 \mathrm{~g} \cdot \mathrm{L}^{-1}$ quartz sand, $24-48 \mathrm{~h}$ was the optimum reaction time for municipal sewage sludge bioleaching mediated by $A$. ferrooxidans LX5, and the best concentration of $\mathrm{Fe}^{2+}$ energy sources was $4-6 \mathrm{~g} \cdot \mathrm{L}^{-1}$. 
Author Contributions: Y.S. conceived and designed this study, conducted the data collation and analysis, and wrote the manuscript. Y.M., Y.W., and Z.G. performed the experiments, conducted the data collation and analysis, and wrote the manuscript. H.W. contributed to revision of the manuscript. All read and approved the final manuscript.

Funding: This research was funded by the Natural Science Foundation of Hubei Province, China (Grant No. 2016CFB289), and the Talent Introduction Foundation of Zhongnan University of Economics and Law (Grant No. 31541711302).

Acknowledgments: The authors express their sincere gratitude to the Longwangzui Wastewater Treatment Plant in Wuhan City for kindly providing samples.

Conflicts of Interest: The authors declare no conflicts of interest.

\section{References}

1. Zhou, L.X.; Fang, D.; Wang, S.M.; Wong, J.W.C.; Wang, D.Z. Bioleaching of Cr from tannery sludge: The effects of initial acid addition and recycling of acidified bioleached sludge. Environ. Technol. 2005, 26, 277-284. [CrossRef] [PubMed]

2. Tyagi, R.D.; Sreekrishnan, T.R.; Blais, J.F.; Surampalli, R.Y.; Campbell, P.G.C. Effect of dissolved oxygen on sludge acidification during the SSDML process. Water Air Soil Pollut. 1998, 102, 139-155. [CrossRef]

3. Zhou, L.X.; Zhou, S.G.; Wang, S.M.; Fang, D.; Wang, D.Z. Cr removal and improving the settling and dehydrating capability from tannery sludge simultaneously through bioleaching approach. Acta Sci. Circum. 2004, 6, 1014-1020.

4. Wang, D.Z.; Zhou, L.X.; He, F. Studies on the enhancement of dehydration property of tannery sludge by bioleaching technique. China Environ. Sci. 2006, 26, 67-71.

5. Song, X.W.; Zhou, L.X. The influence of bioleaching on dewaterability of municipal sewage sludge. Acta Sci. Circum. 2008, 28, 2012-2017.

6. Chen, H.; Zhou, L.X.; Li, C. The removal of Cr from tannery sludge by bioleaching in air-lift reactor: A pilot study. Environ. Sci. 2007, 28, 2046-2051.

7. Liu, F.W.; Zhou, L.X.; Zhou, J.; Song, X.W.; Wang, D.Z. Improvement of sludge dewaterability and removal of sludge-borne metals by bioleaching at optimum pH. J. Hazard. Mater. 2012, 221, 170-177. [CrossRef] [PubMed]

8. Zhou, J.; Zheng, G.; Wong, J.W.; Zhou, L. Degradation of inhibitory substances in sludge by Galactomyces sp. $\mathrm{Z3}$ and the role of its extracellular polymeric substances in improving bioleaching. Bioresour. Technol. 2013, 132, 217-223. [CrossRef] [PubMed]

9. Murugesan, K.; Ravindran, B.; Selvam, A.; Kurade, M.B.; Yu, S.M.; Wong, J.W. Enhanced dewaterability of anaerobically digested sewage sludge using Acidithiobacillus ferrooxidans culture as sludge conditioner. Bioresour. Technol. 2014, 169, 374-379. [CrossRef] [PubMed]

10. Wong, J.W.C.; Xiang, L.; Gu, X.Y.; Zhou, L.X. Bioleaching of heavy metals from anaerobically digested sewage sludge using $\mathrm{FeS}_{2}$ as an energy source. Chemosphere 2004, 55, 101-107. [CrossRef] [PubMed]

11. Xiang, L.; Chan, L.C.; Wong, J.W.C. Removal of heavy metals from anaerobically digested sewage sludge by isolated indigenous iron-oxidizing bacteria. Chemosphere 2000, 41, 283-287. [CrossRef]

12. Wang, H.M.; Min, X.B.; Chai, L.Y.; Shu, Y.D. Biological preparation and application of poly-ferric sulfate flocculant. Trans. Nonferrous Met. Soc. China 2011, 21, 2542-2547. [CrossRef]

13. Liao, Y.; Zhou, L.; Bai, S.; Liang, J.; Wang, S. Occurrence of biogenic schwertmannite in sludge bioleaching environments and its adverse effect on solubilization of sludge-borne metals. Appl. Geochem. 2009, 24, 1739-1746. [CrossRef]

14. Zhou, J.; Zhou, L.; Liu, F.; Zheng, C.; Deng, W. Transformation of heavy metals and the formation of secondary iron minerals during pig manure bioleaching by the co-inoculation acidophilic thiobacillus. Environ. Technol. 2012, 33, 2553-2560. [CrossRef] [PubMed]

15. Control Standards of Pollutants in Sludge for Agricultural Use; GB 4284-2018; Inspection and Quarantine of the People's Republic of China: Beijing, China, 2018.

16. Guo, G.H.; Chen, T.B.; Yang, J.; Zheng, G.; Ding, G. Regional distribution characteristics and variation of heavy metals in sewage sludge of China. Acta Sci. Circum. 2014, 34, 2455-2461.

17. Sasaki, K.; Konno, H. Morphology of jarosite-group compounds precipitated from biologically and chemically oxidized Fe ions. Can. Mineral. 2000, 38, 45-56. [CrossRef] 
18. Karamanev, D.G. Model of the biofilm structure of Thiobacillus ferrooxidans. J. Biotechnol. 1991, 20, 51-64. [CrossRef]

19. Jensen, A.B.; Webb, C. Ferrous sulphate oxidation using Thiobacillus ferrooxidans: A review. Process Biochem. 1995, 30, 225-236. [CrossRef]

20. Dutrizac, J.E. The effect of seeding on the rate of precipitation of ammonium jarosite and sodium jarosite. Hydrometallurgy 1996, 42, 293-312. [CrossRef]

21. Wang, M.; Zhou, L.X. The removal of soluble ferrousiron in acid mine drainage (AMD) through the formation of biogenic iron oxyhydrosulfate precipitates facilitated by diatomite, quartz sand and potassium. Acta Petrol. Mineral. 2011, 30, 1031-1038.

22. Tichý, R.; Janssen, A.; Grotenhuis, J.T.C.; Lettinga, G.; Rulkens, W.H. Possibilities for using biologically-produced sulphur for cultivation of Thiobacillus with respect to bioleaching processes. Bioresour. Technol. 1994, 48, 221-227. [CrossRef]

23. American Public Health Association. APHA: Standard Methods for the Examination of Water and Wastewater; American Public Health Association: Washington, DC, USA, 2005.

24. Liu, F.W.; Gao, S.Y.; Wang, M.; Yu, H.Y.; Cui, C.H.; Zhou, L.X. Effect of KOH on the formation of biogenic secondary iron minerals in iron- and sulfate-rich acidic environment. Acta Sci. Circum. 2015, 35, 476-483.

25. Loan, M.; Richmond, W.R.; Parkinson, G.M. On the crystal growth of nanoscale schwertmannite. J. Cryst. Growth 2005, 275, 1875-1881. [CrossRef]

26. Jönsson, J.; Persson, P.; Sjöberg, S.; Lövgren, L. Schwertmannite precipitated from acid mine drainage: phase transformation, sulfate release and surface properties. Appl. Geochem. 2005, 20, 179-191. [CrossRef]

27. Šubrt, J.; Boháček, J.; Štengl, V.; Grygar, T.; Bezdička, P. Uniform particles with a large surface area formed by hydrolysis of $\mathrm{Fe}_{2}\left(\mathrm{SO}_{4}\right)_{3}$ with Urea. Mater. Res. Bull. 1999, 34, 905-914. [CrossRef]

28. Hongfu, S.; Fenghua, Z.; Zhiyuan, C. The mineral Schwertmannite found in China and its characteristics. Acta Mineral. Sin. 2006, 26, 38-42.

29. Singer, P.C.; Stumm, W. Acidic mine drainage: The rate determining step. Science 1970, 167, 1121-1123. [CrossRef] [PubMed]

30. Umita, T. Biological mine drainage treatment. Resour. Conserv. Recycl. 1996, 16, 179-188. [CrossRef]

31. Bosecker, K. Bioleaching: Metal solubilization by microorganisms. FEMS. Microbiol. Rev. 1997, 20, 591-604. [CrossRef]

32. Harahuc, L.; Lizama, H.M.; Suzuki, I. Selective inhibition of the oxidation of ferrous iron or sulfur in Thiobacillus ferrooxidans. Appl. Environ. Microbl. 2000, 66, 1031-1037. [CrossRef]

33. Bai, S.Y.; Liang, J.R.; Zhou, L.X. Effects of iron/potassium molar ratio on mass of biogenic Fe(III) hydroxysulfate precipitates in the $\mathrm{FeSO}_{4}-\mathrm{K}_{2} \mathrm{SO}_{4}-\mathrm{H}_{2} \mathrm{O}$ system and their environmental implications. Acta Sci. Circum. 2010, 30, 1601-1607.

34. Regenspurg, S.; Brand, A.; Peiffer, S. Formation and stability of schwertmannite in acid mining lakes 1. Geochim. Cosmochim. Acta 2004, 68, 1185-1197. [CrossRef]

35. International Center for Diffraction Data. JCPDS-Mineral Powder Diffraction Files; International Center for Diffraction Data: Swarthmore, PA, USA, 2002.

(c) 2018 by the authors. Licensee MDPI, Basel, Switzerland. This article is an open access article distributed under the terms and conditions of the Creative Commons Attribution (CC BY) license (http:// creativecommons.org/licenses/by/4.0/). 